Niepełnosprawność. Dyskursy pedagogiki specjalnej

Piotr Plichta, Jacek Pyżalski

Instytut Medycyny Pracy w Łodzi

\title{
Narażenie uczniów ze specjalnymi potrzebami edukacyjnymi na hazard tradycyjny i internetowy oraz inne zachowania ryzykowne
}

\author{
The involvement of students with special educational needs \\ in traditional and online gambling and other risk behaviours
}

The article focuses on the engagement of young people with special educational needs (SEN) in traditional and online gambling as well as other risk behaviours. Gambling can have serious destructive individual, social, and public health consequences, especially when we consider the involvement of young people who come from a vulnerable group (e.g. students with SEN). The article presents an overview of a research on the reported gambling experience (behaviour) and gambling consequences that was conducted with a new diagnostic tool (Lodz Adolescent Gambling Symptoms Questionnaire - LAGSQ). The data confirms that the involvement in gambling within the SEN sample ranged from $8 \%$ to $54 \%$ depending on the type of gambling behavior. The comparison of the results between the SEN sample and the students without SEN reveals statistically significant differences concerning the reported gambling experience and its consequences. Moreover, the students with SEN are more likely to report a higher level of bullying and cyberbullying victimization experience.

Słowa kluczowe: zachowania ryzykowne, hazard, specjalne potrzeby edukacyjne, bullying, cyberbullying

Keywords: risk behaviour, gambling, special educational needs, bullying, cyberbullying

\section{Wprowadzenie}

Artykuł koncentruje się na kwestii zaangażowania w hazard (tradycyjny i internetowy) młodych ludzi z tzw. specjalnymi potrzebami edukacyjnymi (SPE). Skutki hazardu i innych zachowań ryzykownych mogą mieć destruktywny charakter zarówno w sensie indywidualnym, społecznym, jak i w wymiarze zdrowia publicznego, a wiedza na temat zaangażowania w nie uczniów ze SPE ma bardzo 
ograniczony charakter. W zależności od rodzaju zachowania hazardowego, wyniki uzyskane za pomocą Łódzkiego Kwestionariusza Problemów Hazardowych wśród Adolescentów (ŁKPHA) pokazują, że przynajmniej jeden raz w roku poprzedzającym badanie, zrealizowało je od $8 \%$ do $54 \%$ uczniów ze SPE. Porównanie z uczniami bez specjalnych potrzeb edukacyjnych wykazało istotne różnice zarówno w zakresie częstotliwości realizowania zachowań hazardowych, jak i skali nasilenia problemów z nich wynikających. Odnotowano również występowanie większego ryzyka stania się ofiarą przemocy (bullyingu i cyberbullyingu) w przypadku uczniów ze SPE.

Młodzież ze specjalnymi potrzebami edukacyjnymi (SPE), w tym z niepełnosprawnościami, według wielu badaczy należy do grupy podwyższonego ryzyka zaangażowania $\mathrm{w}$ zachowania ryzykowne, $\mathrm{w}$ tym przemoc rówieśniczą (szczególnie $\mathrm{w}$ aspekcie wiktymizacyjnym). Takie zjawisko określa się również podatnością na zranienie (vulnerability). Mimo istniejących przesłanek, głównie o charakterze praktycznym, należy zauważyć jednak niedosyt badań w tym zakresie (szczególnie w krajowym piśmiennictwie). Stan taki uzasadnia potrzebę pogłębionej analizy uwarunkowań i rozpowszechnienia zachowań ryzykownych młodzieży ze specjalnymi potrzebami edukacyjnymi zarówno w tradycyjnym wymiarze (offline), jak i w kontekście używania nowoczesnych technologii informacyjno-komunikacyjnych (TIK). To ostatnie uzasadnione jest faktem, że wiele zachowań ryzykownych (np. hazard, przemoc rówieśnicza) może być realizowane za pomocą instrumentów TIK i w środowisku online.

$\mathrm{W}$ niniejszym artykule $\mathrm{w}$ największym stopniu uwaga zostanie poświęcona zachowaniom hazardowym. Przedstawiona analiza jest fragmentem badań zrealizowanych w Instytucie Medycyny Pracy w Łodzi na zlecenie Krajowego Biura do spraw Przeciwdziałania Narkomanii ${ }^{1}$. Istotnym elementem opisu będzie również porównanie rozpowszechnienia innych zachowań ryzykownych $w$ populacji uczniów z tzw. specjalnymi potrzebami edukacyjnymi z wynikami populacji generalnej, dotyczącymi używania substancji psychoaktywnych i zaangażowania w przemoc rówieśniczą (tradycyjną i internetową).

$\overline{1}$ Nazwa projektu: „Konstrukcja i walidacja narzędzia kwestionariuszowego do pomiaru rozpowszechnienia hazardu problemowego i patologicznego (w tym online) wśród adolescentów". Okres realizacji 1 lipca 2014 - 31 grudnia 2015. Zespół projektowy Krajowego Centrum Promocji Zdrowia w Miejscu Pracy, kierownik projektu - J. Pyżalski. Badania te wynikały z realizacji 1 Programu Ministra Zdrowia pn. „Wspieranie badań naukowych dotyczących zjawiska uzależnienia od hazardu lub innych uzależnień niestanowiących uzależnienia od substancji psychoaktywnych, a także rozwiązywania problemów z tym związanych", zadanie 6: „Przeprowadzenie badań naukowych służących pogłębieniu wiedzy w zakresie uzależnień behawioralnych, $\mathrm{w}$ tym hazardu problemowego i patologicznego psychoaktywnych, a także rozwiązywania problemów z tym związanych". 


\section{Zachowania ryzykowne a specjalne potrzeby edukacyjne}

Zachowania ryzykowne są pojemną kategorią. Należą do nich różne aktywności (np. hazard, używanie środków psychoaktywnych, zaangażowanie w agresję, samouszkodzenia, przedwczesna aktywność seksualna), będące potencjalną przyczyną poważnych, negatywnych konsekwencji zarówno dla zdrowia jednostki (fizycznego i psychicznego), jak i dla jej otoczenia społecznego np. rodziny. Zachowania bywają również przejawami naruszenia norm społecznych. Zdaniem Lipińskiej-Lokś pojawia się obecnie potrzeba refleksji dotyczącej niepełnosprawności jako swoistego czynnika sprzyjającego występowaniu u dzieci i młodzieży zachowań ryzykownych „podejmowanych w celu złagodzenia negatywnych jej konsekwencji w sferze psychicznej i społecznej funkcjonowania osoby oraz rozwiązania jej sytuacji trudnej (s. 24)". Tzw. specjalne potrzeby edukacyjne, w tym niepełnosprawność, są również (podobnie jak hazard) obszernym znaczeniowo pojęciem. Mimo wspólnej kategorii ${ }^{2}$, uczniowie tak określani nie stanowią jednolitej grupy. Co więcej, populacja ta jest wewnętrznie zróżnicowana w niezwykle dużym stopniu - m.in. należą do tej grupy uczniowie z niepełnosprawnością intelektualną, ze spektrum autystycznego, zagrożeni niedostosowaniem społecznym, ze specyficznymi trudnościami w uczeniu się oraz szczególnie uzdolnieni.

Badania pokazują szczególne zaangażowanie tej grupy osób w zachowania ryzykowne (np. McBrien, Hodgetts, Gregory 2003; Clark, Nower, Walker 2013) oraz podwyższone ryzyko narażenia na szeroko rozumianą agresję rówieśniczą (m.in. Little 2002; Mishna 2003; Nabuzoka 2003; Rose i wsp. 2001 i 2015). Livingstone i Palmer (2012) potwierdzają, że osoby z grup "podwyższonego ryzyka” $\mathrm{w}$ tradycyjnie rozumianej przestrzeni społecznej są również bardziej narażone na negatywne konsekwencje związane z korzystaniem z Internetu. Pyżalski w typologii agresji elektronicznej (2010) wyróżnia "agresję wobec pokrzywdzonych" (m.in. niepełnosprawnych, chorych, uzależnionych) jako przejaw realizowania wrogich działań online $\mathrm{w}$ stosunku do osób słabszych, którym trudniej jest się bronić.

Adolescencja jest okresem sprzyjającym eksperymentowaniu z własną tożsamością $\mathrm{i}$ angażowaniu się w zachowania ryzykowne. Najczęściej jednak próby te mają charakter tymczasowy i nie wywierają poważnych skutków w przyszłości. Uwzględniając wyższe ryzyko występowania problemów dotyczących zdrowia

2 Rozporządzenie Ministra Edukacji Narodowej z dnia 18 września 2008 r. w sprawie orzeczeń i opinii wydawanych przez zespoły orzekające działające $\mathrm{w}$ publicznych poradniach psychologicznopedagogicznych określa je jako „indywidualne potrzeby rozwojowe i edukacyjne. Specjalne potrzeby edukacyjne definiowane są również poprzez posiadanie orzeczenia o potrzebie kształcenia specjalnego wydawanego przez poradnie psychologiczno-pedagogiczne. 
psychicznego w grupie młodych ludzi z tzw. specjalnymi potrzebami edukacyjnymi (Rose i wsp. 2009), zjawisku takiemu należy poświęcić więcej uwagi. Pozwoli to na wczesną identyfikację problemów i w konsekwencji podejmowanie interwencji, które $w$ początkowej fazie występowania problemów są znacznie skuteczniejsze niż wtedy, gdy mamy do czynienia z zaawansowanymi zachowaniami ryzykownymi.

\section{Ryzyko uzależnienia od hazardu}

Hazard jest przykładem zachowania ryzykownego, którego skutki w przypadku młodych ludzi mogą być szczególnie destruktywne (zarówno w sensie indywidualnym, społecznym, jak i w wymiarze zdrowia publicznego). Ujęcia słownikowe hazardu często zawężone bywają do działań mających charakter gry, których wynik (najczęściej pieniądze) zależy od przypadku. Warto jednak zauważyć, że nagrodami mogą być również przedmioty lub inne nagrody o charakterze niematerialnym. Gry hazardowe mogą odbywać się w kasynach, w punktach zakładów wzajemnych, ale również gry realizowane w Internecie są z reguły odpowiednikiem tradycyjnych gier (np. ruletki). Do charakterystyki podejmowanego zjawiska można zaliczyć również konkursy telefoniczne i loterie smsowe organizowane np. przez media czy operatorów sieci komórkowych (Pyżalski, Petrykowska, Plichta 2015). Z badań polskich, jak i zagranicznych wynika, iż zjawisko to jest dość rozpowszechnione, np. co trzeci Polak powyżej 15 r.ż. zadeklarował, iż w ciągu 12 miesięcy poprzedzających badanie grał w jakieś gry na pieniądze (Gwiazda 2015, s. 2). Nie zawsze granie rekreacyjne przynosi negatywne skutki, ale często jest "wstępem”, punktem wyjścia do grania problemowego i poważniejszych konsekwencji. Hazard może mieć charakter społeczny (rekreacyjny) lub problemowy. Ten ostatni ma miejsce wtedy, gdy osoba lub jej najbliżsi ponoszą negatywne następstwa związane z uprawianiem omawianej czynności. Najpoważniejszy zaś jest hazard patologiczny, który został zdefiniowany w Międzynarodowej Statystycznej Klasyfikacji Chorób i Problemów Zdrowotnych ICD-10 (Woronowicz 2011) oraz w DSM-V (Jarczyńska 2014, s. 74-75). W tym ostatnim uwzględnia się następujące symptomy:

1. potrzebę podwyższania stawek, pieniędzy, służących osiąganiu pobudzenia emocjonalnego;

2. podenerwowanie lub poirytowanie $w$ sytuacjach zaprzestania grania;

3. wielokrotne podejmowanie nieskutecznych prób mających na celu kontrolowanie, ograniczenie lub zaprzestanie hazardowego grania; 
4. częste zaabsorbowanie hazardem (np. przypominanie sobie wcześniejszych doświadczeń związanych z graniem, planowanie następnej gry, myślenie o sposobach zdobycia pieniędzy na grę hazardową);

5. częste granie dla poprawy złego samopoczucia (np. uczucia bezradności, poczucia winy);

6. częste podejmowanie prób odzyskania pieniędzy np. następnego dnia po przegranej w grze (chęć „odegrania się");

7. okłamywanie w celu ukrycia prawdziwych rozmiarów swojego hazardowego grania;

8. narażenie na szwank ważnych relacji, pracy, nauki i kariery zawodowej z powodu zaangażowania $\mathrm{w}$ granie;

9. szukanie $\mathrm{u}$ innych pomocy finansowej $\mathrm{w}$ celu poprawienia złej sytuacji ekonomicznej wynikającej z hazardu.

Przyjmuje się występowanie minimum 4 symptomów w ciągu 12 miesięcy u osoby diagnozowanej, aby można było wnioskować o hazardzie (za: Petrykowska, Pyżalski, Plichta 2015).

Zaangażowanie $\mathrm{w}$ zachowania $\mathrm{z}$ zakresu hazardu (online i offline) wśród młodzieży są zjawiskiem dość powszechnym (m.in. Gupta, Derevensky 1998; Wanner i in. 2006) i współwystępuje z innymi zachowaniami problemowymi, jak $n p$. popełnianie przestępstw oraz nadużywanie substancji psychoaktywnych (Winters \& Anderson 2000; Vitaro i in. 2001; Gibbs Van Brunschott 2009; Brunelle $i$ in. 2012). Odsetek młodych ludzi zaangażowanych w hazard (4,1\% ryzykowny i $2 \%$ patologiczny) w kanadyjskich badaniach (Brunelle i in. 2012) okazał się wyższy niż wśród dorosłych. Kiedy przyjrzymy się liczbie młodych osób angażujących się $\mathrm{w}$ tradycyjny hazard (przynajmniej jeden raz $\mathrm{w}$ roku poprzedzającym badanie) odsetki należy uznać za niepokojące: 37\% w badaniach uczniów szkół ponadgimnazjalnych (Martin i In. 2008) i 65\% 12-17-latków w badaniach Jacobs (2004). Problem ryzyka hazardu jest rozpoznawany wśród względnie jednorodnych grup np. z niepełnosprawnością intelektualną (Borowska-Beszta, 2006; Hintze 2011; Groombridge, Gordon, Tierney 2000), ale również $\mathrm{w}$ perspektywie szeroko rozumianej populacji osób ze specjalnymi potrzebami edukacyjnymi (Parker i in. 2013).

Uzależnienia behawioralne (np. hazard) realizowane są również z wykorzystaniem nowoczesnych technologii informacyjno-komunikacyjnych. Zarówno "tradycyjny" (offline) hazard, jak i nadmierne, problemowe korzystanie z Internetu (Excessive Internet Use, Problematic Internet Use) mają wiele wspólnego pod względem uwarunkowań. Mówi się również o, do pewnego stopnia, wspólnym profilu psychologicznym osób narażonych na wymienione wcześniej problemy (Dowling, Brown 2010). Warto w tym miejscu zauważyć, że tradycyjne zachowania ryzykowne łatwiej mogą być zidentyfikowane w porównaniu z dysfunkcjo- 
nalnymi doświadczeniami w Internecie, co wynika z ograniczonych możliwości monitorowania aktywności online młodych ludzi przez dorosłych.

Powszechność korzystania z Internetu oznacza przenoszenie się do tego środowiska zarówno zachowań pozytywnych, jak i ryzykownych. Te ostatnie w połączeniu z większym poczuciem anonimowości prowadzą czasem do poważnych skutków o charakterze indywidualnym oraz społecznym. W analizie korzystania (w tym problemowego) z Internetu należy, oprócz właściwości samego środowiska cyfrowego, brać pod uwagę interakcję ze specyfiką funkcjonowania osób ze specjalnymi potrzebami edukacyjnymi (Plichta 2013). Mechanizmy komunikowania się w sposób zapośredniczony (computer mediated communication) pojawiające się podczas korzystania nowych mediów, np. rozhamowanie zwiększa zarówno gotowość do ujawniania osobistych informacji na swój temat, jak i inne zachowania, których nie podjęłoby się w bezpośrednich kontaktach „twarzą w twarz". Zjawisko to, z punktu widzenia użytkowników nowych mediów, w tym ze specjalnymi potrzebami edukacyjnymi, posiada oczywiste zalety (np. możliwość autoprezentacji), jak i przynosi pewne ryzyko (np. zaangażowanie w agresję). Zgodnie z ogólnymi koncepcjami zachowań dewiacyjnych zaangażowanie w jeden rodzaj aktywności zwiększa ryzyko kolejnych zachowań o charakterze patologicznym (np. Donovan i Jessor 1985). Na przykład sprawcy agresji elektronicznej podejmują zwykle inne „tradycyjne” zachowania ryzykowne, częściej niż osoby niebędące sprawcami używają środków psychoaktywnych, mają gorsze relacje z rodzicami oraz osiągają wyższe wskaźniki w skali depresji (Ybarra, Mitchell 2004; Ybarra, Mitchell, Lenhart 2010, za: Pyżalski 2012).

Szczególnie trudna (zarówno w środowisku tradycyjnym, jak i cyfrowym) jest sytuacja młodych ludzi, którzy posiadają ograniczone kompetencje psychospołeczne pozwalające na uniknięcie lub poradzenie sobie z trudnymi, ryzykownymi sytuacjami np. dotyczy to narażenia na ryzyko sytuacji krzywdzenia (bullyingu), czyli takiej formy agresji rówieśniczej, którą cechuje intencjonalność, powtarzalność i nierównowaga sił. Szczególnie ta ostatnia właściwość stanowi poważne zagrożenie dla młodych ludzi znajdujących się w trudniejszej sytuacji osobistej i społecznej, np. dla uczniów ze specjalnymi potrzebami edukacyjnymi, z niepełnosprawnościami (Plichta, Olempska-Wysocka 2013).

\section{Metodologia badań własnych}

\section{Problemy badawcze}

Prezentowane wyniki badań będą stanowiły próbę odpowiedzi na następujące pytania badawcze dotyczące uczniów ze specjalnymi potrzebami edukacyjnymi: 
1. Jakie jest rozpowszechnienie zachowań hazardowych w ciągu 12 miesięcy poprzedzających badanie?

2. Jaki jest stopień nasilenia problemów hazardowych?

3. Jakie jest rozpowszechnienie używania środków psychoaktywnych?

4. Jakie jest rozpowszechnienie tradycyjnego i internetowego dręczenia (bullyingu i cyberbullyingu)?

5. Jakie są różnice $w$ zakresie analizowanych zachowań ryzykownych między uczniami ze specjalnymi potrzebami edukacyjnymi i uczniami bez specjalnych potrzeb edukacyjnych?

\section{Narzędzie badawcze}

Użytym narzędziem badawczym był Łódzki Kwestionariusz Problemów Hazardowych wśród Adolescentów (ŁKPHA), którego powstanie poprzedził etap badań jakościowych polegający na przeprowadzeniu indywidualnych wywiadów pogłębionych z terapeutami zajmującymi się profilaktyką i leczeniem uzależnień behawioralnych wśród młodzieży oraz pilotaż w populacji docelowej. ŁKPHA obejmuje następujące skale: Częstotliwości Grania, Natężenia Problemów Hazardowych oraz Nieracjonalnego Myślenia Hazardowego. Skala Natężenia Problemów Hazardowych przygotowana została na podstawie objawów uzależnienia od hazardu zdefiniowanych w DSM-V. Narzędzie może służyć do badań populacyjnych i indywidualnych (jako narzędzie pomocnicze). Pozwala ono $\mathrm{z}$ jednej strony prowadzić badania przesiewowe - wskazujące na rozpowszechnienie grania i związanych z nim problemów (w tym uzależnienia). $Z$ drugiej strony może służyć jako narzędzie pomocnicze w pracy klinicznej - do diagnozy indywidualnej. Narzędzie charakteryzuje się dobrymi właściwości psychometrycznymi (wartości standaryzowane alfa Cronbacha, w zależności od skali wyniosły od 0,92 do 0,98 ). Narzędzie posiada również normy stenowe ustalone w reprezentatywnej ogólnopolskiej próbie młodzieży (Pyżalski, Petrykowska, Plichta 2015).

\section{Próba badawcza}

Badania przeprowadzono na losowej, ogólnopolskiej próbie 1505 uczniów, w wieku 13-18 lat z terenu całego kraju (50\% badanych stanowili chłopcy, 48,5\% dziewczęta, a 1,5\% respondentów nie zaznaczyło opcji wyboru płci). Próba została uzyskana poprzez losowanie warstwowe szkół z terenu całego kraju oraz klas w wylosowanych szkołach.

Używanie terminu „specjalnych potrzeb edukacyjnych" w literaturze ma nieostry charakter (np. Chrzanowska 2015), co odnosi się również do kryteriów użytych w omawianych badaniach. W prezentowanym artykule zaliczenie do tej gru- 
py wynikało z pozytywnego wskazania respondentów w odpowiedzi na pytanie: "Czy masz orzeczenie o niepełnosprawności lub inny podobny dokument np. o dysleksji". Respondenci, którzy udzielili twierdzącej odpowiedzi na to pytanie, stanowili $13 \%$ próby $(\mathrm{N}=203)$. Oczywiście podejście takie posiada swoje ograniczenia - jednak pozwala na osiągnięcie celu jakim jest wstępne rozpoznanie zjawiska rozpowszechnienia zachowań ryzykownych wśród młodych ludzi ze specjalnymi potrzebami edukacyjnymi i porównanie ich z wynikami "typowo rozwijających się" rówieśników. Warto przy okazji zauważyć znaczne rozpowszechnienie korzystania z tzw. korepetycji lub innych form pomocy nauce. Na pytanie: „Czy w ciągu ostatnich 12 miesięcy z powodu trudności korzystałeś/aś $\mathrm{z}$ pomocy $\mathrm{w}$ nauce np. uczestniczyłeś/aś $\mathrm{w}$ dodatkowych zajęciach $\mathrm{z}$ jakiegoś przedmiotu, korepetycjach? Twierdząco odpowiedziały 763 osoby stanowiące $51 \%$ próby badawczej. Przyjęty poziom istotności w omawianych badaniach wynosi p?0,05. Do analizy rozkładów częstości odpowiedzi wykorzystany będzie test chi-kwadrat Pearsona (w zależności od potrzeb - z poprawką Yatesa).

\section{Wyniki badań własnych}

\section{Zachowania hazardowe}

Analizy rozpoczęto od behawioralnej analizy zaangażowania w hazard - czyli faktu podejmowania określonych działań o tym charakterze $w$ ciągu roku poprzedzającego badanie. $\mathrm{W}$ poniższej tabeli zawarte są dane przedstawiające porównanie rozpowszechnienia zachowań hazardowych między młodymi ludźmi określanymi jako uczniowie ze specjalnymi potrzebami edukacyjnymi a ich typowo rozwijającymi się rówieśnikami.

Z wyników zawartych w powyższej tabeli 1 wynika, że badane grupy różnią się istotnie pod względem rozpowszechnienia w zakresie $7 \mathrm{z} 13$ analizowanych zachowań hazardowych. Co warte zauważenia - tam gdzie wystą̧iły istotne różnice, w niemal każdym przypadku wskazywały na większe rozpowszechnienie danego zachowania ryzykownego $\mathrm{w}$ grupie młodych ludzi ze specjalnymi potrzebami edukacyjnymi, co częściowo potwierdza słuszność tezy o podwyższonej podatności na zachowania ryzykowne tej grupy uczniów. Dotyczyło to następujących zachowań hazardowych:

- grania na pieniądze na automatach/maszynach (tzw. jednorękich bandytach/ owocówkach);

- grania na prawdziwe pieniądze/rzeczy w gry planszowe, np. Monopol;

- stawiania pieniędzy/zakładów dotyczących wyników sportowych w internecie; 


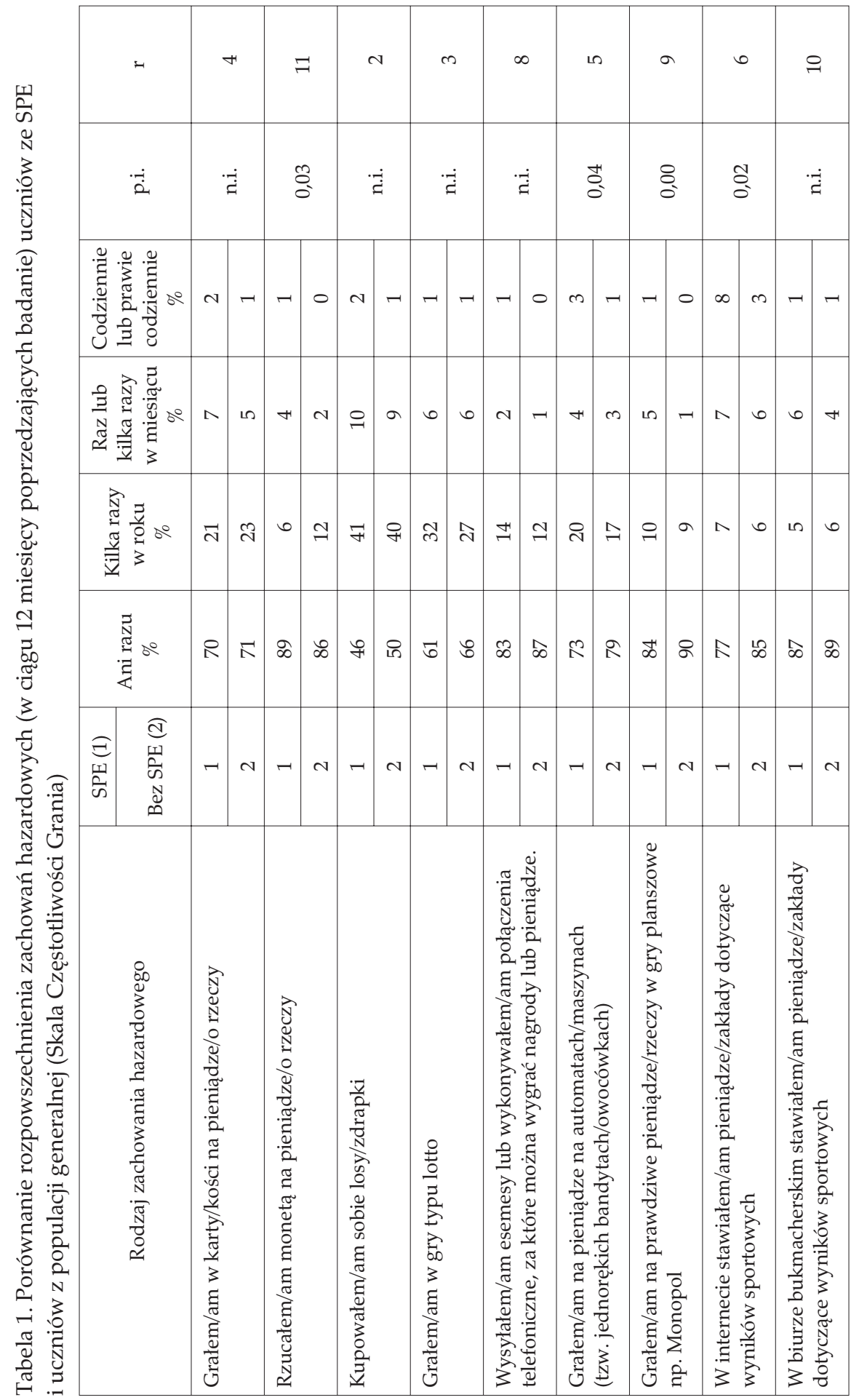




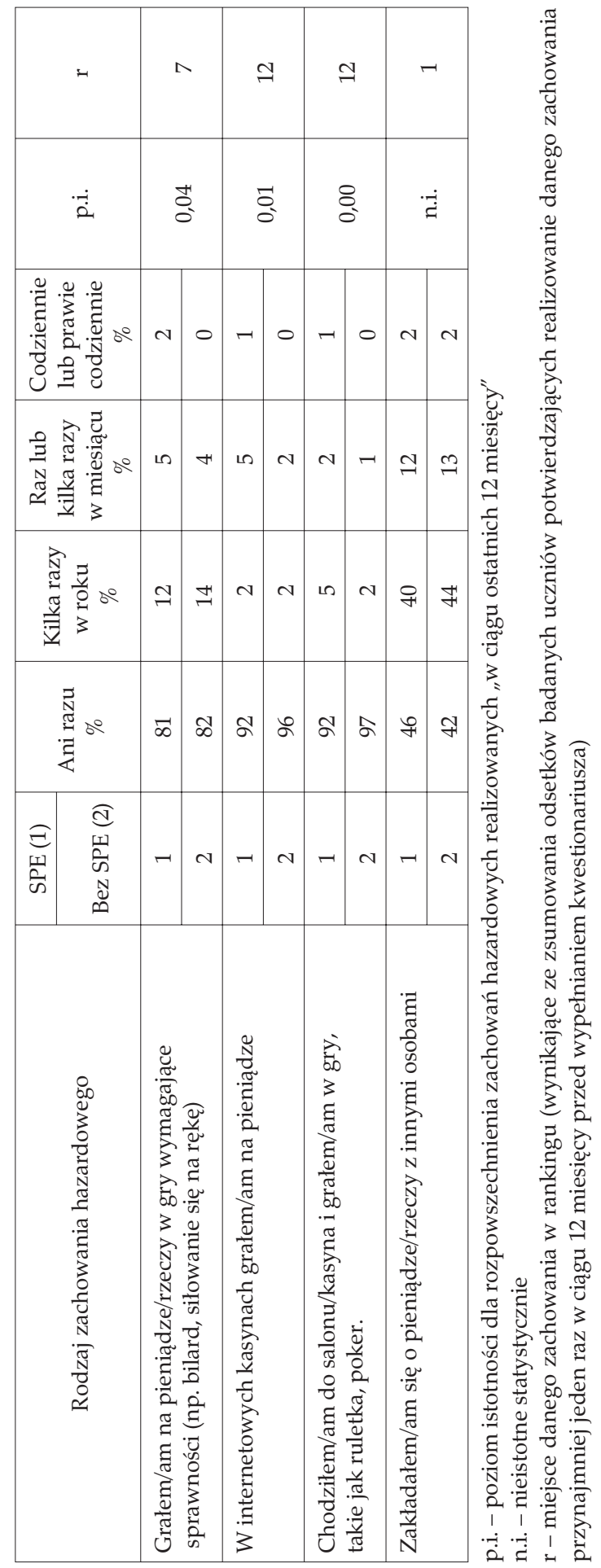


- grania na pieniądze/rzeczy w gry wymagające sprawności (np. bilard, siłowanie się na rękę);

- grania na pieniądze w kasynach internetowych;

- grania w kasynie, salonie gier w takie gry jak ruletka, poker.

Jedynym zachowaniem, które realizowane było istotnie częściej w grupie bez specjalnych potrzeb edukacyjnych, było „rzucanie monetą, żeby wygrać pieniądze/o rzeczy", które w zestawieniu z zachowaniami częściej podejmują uczniowie ze SPE, należy potraktować jako mniej poważne.

Odsetki osób realizujących poszczególne zachowania są najniższe w przypadku korzystania z "tradycyjnego" kasyna (łącznie 8\% osób zadeklarowało, że w ciągu roku grało tam przynajmniej jeden raz), grania na pieniądze w internetowych kasynach (8\%), a najwyższe w zakładaniu się o pieniądze/rzeczy z innymi osobami (54\%) i kupowanie losów, zdrapek (53\%). Szczegółowy ranking zachowań hazardowych zrealizowanych przez badanych uczniów jest przedstawiony w powyższej tabeli w kolumnie oznaczonej literą ",r" (gdzie cyfra 1 oznacza zachowania najczęściej realizowane, a liczba 12 - najrzadziej).

Prezentowane wyniki nie stanowią odpowiedzi na pytanie o występowanie uzależnienia od hazardu, a przedstawiają jedynie rozpowszechnienie pojedynczych zachowań o charakterze hazardowym.

\section{Nasilenie Problemów Hazardowych}

Następny analizowany aspekt to występowanie problemów hazardowych, czyli sytuacji, gdzie graniu towarzyszą problemy w funkcjonowaniu lub społeczne (zdefiniowane w podręczniku DSM-V. W kolejnej tabeli 2 umieszczone są odsetki odpowiedzi (uczniów ze specjalnymi potrzebami edukacyjnymi) na pytanie: czy i jak często w ciągu 12 miesięcy poprzedzających badanie zdarzyły się im następujące sytuacje wskazujące na nasilenie problemów wynikających z hazardu. (Wyniki nie sumują się do 100\% - dotyczą tylko uczniów, którzy zrealizowali jakiekolwiek zachowanie hazardowe w ciągu roku przed badaniem). Ze względu na ograniczoną ilość miejsca i troskę o czytelność danych nie podano tu wyników uczniów bez specjalnych potrzeb edukacyjnych.

W zakresie 13 na 20 porównywanych zachowań - konsekwencji hazardu, istotnie większe ich rozpowszechnienie odnotowano w grupie uczniów ze specjalnymi potrzebami edukacyjnymi. Dotyczyło to następujących zachowań: powrotu do grania mimo postanowienia zaprzestania, prób szybkiego odegrania się, zadłużania się, grania w celu ucieczki od problemów, komunikatów ze strony innych o postrzeganych problemach z graniem, ukrywania przed innymi stawek, 
psucia się relacji z bliskimi, zwiększania się wartości sum i rzeczy, o które się grało, odczuwania przyjemności z gry o wysokie stawki, kontynuowania grania mimo znacznych strat, rozmyślania wcześniejszych wygranych, przypominania sobie sytuacji towarzyszących graniu, oszukiwania, żeby zdobyć pieniądze/rzeczy na granie oraz „zarywania” nocy, żeby grać na pieniądze/rzeczy.

Tabela 2. Rozpowszechnienie zachowań ze Skali Natężenia Problemów Hazardowych realizowanych przez uczniów ze specjalnymi potrzebami edukacyjnymi

\begin{tabular}{|c|c|c|c|c|c|}
\hline & $\begin{array}{c}\text { Ani razu } \\
\%\end{array}$ & $\begin{array}{c}1-2 \text { razy } \\
\%\end{array}$ & $\begin{array}{l}\text { Kilka } \\
\text { razy } \\
\%\end{array}$ & $\begin{array}{c}\text { Kilkana- } \\
\text { ście razy } \\
\text { i więcej } \\
\%\end{array}$ & p. i $^{*}$. \\
\hline $\begin{array}{l}\text { Ukrywałem/am przed rodzicami lub innymi } \\
\text { ważnymi dla mnie osobami to, że gram } \\
\text { na pieniądze/rzeczy lub jak dużo gram }\end{array}$ & 67 & 3 & 1 & 2 & n.i. \\
\hline $\begin{array}{l}\text { Wracałem/am do grania na pieniądze/rzeczy, } \\
\text { chociaż postanawiałem/am lub obiecałem/am } \\
\text { innym, że już nie będę grał }\end{array}$ & 67 & 3 & 1 & 2 & 0,00 \\
\hline $\begin{array}{l}\text { Kiedy przegrywałem/am pieniądze/rzeczy } \\
\text { próbowałem/am szybko się odegrać }\end{array}$ & 57 & 5 & 6 & 5 & 0,00 \\
\hline $\begin{array}{l}\text { Żeby grać na pieniądze/rzeczy zadłużałem/am } \\
\text { się u innych osób }\end{array}$ & 69 & 1 & 0 & 2 & 0,00 \\
\hline $\begin{array}{l}\text { Kiedy nie mogłem/am grać na pieniądze/rzeczy } \\
\text { bardziej nerwowo reagowałem/am na inne osoby }\end{array}$ & 69 & 1 & 2 & 0 & n.i. \\
\hline $\begin{array}{l}\text { Wyobrażałem/am sobie, w co i jak będę grał/a, } \\
\text { marzyłem/am o wygranej }\end{array}$ & 52 & 11 & 7 & 2 & n.i. \\
\hline $\begin{array}{l}\text { Próbowałem/am przestać grać na pieniądze/ } \\
\text { rzeczy, ale mi to nie wychodziło }\end{array}$ & 68 & 3 & 1 & 0 & n.i. \\
\hline $\begin{array}{l}\text { Grałem/am na pieniądze/rzeczy, żeby zapomnieć } \\
\text { o problemach }\end{array}$ & 67 & 4 & 2 & 0 & 0,03 \\
\hline $\begin{array}{l}\text { Inne osoby mówiły mi, że powinienem/powin- } \\
\text { nam udać się do specjalisty, ponieważ za dużo } \\
\text { gram na pieniądze/ rzeczy }\end{array}$ & 70 & 1 & 0 & 1 & 0,01 \\
\hline $\begin{array}{l}\text { Mówiłem/am, że stawiałem/am w grach mniej- } \\
\text { sze sumy/rzeczy o mniejszej wartości niż rze- } \\
\text { czywiście stawiałem/am }\end{array}$ & 69 & 2 & 0 & 2 & 0,03 \\
\hline $\begin{array}{l}\text { "Zawalałem/am" naukę w szkole przez to, } \\
\text { że grałem/am na pieniądze/rzeczy }\end{array}$ & 68 & 2 & 2 & 1 & n.i. \\
\hline $\begin{array}{l}\text { Popsuły mi się znajomości z przyjaciółmi / } \\
\text { dziewczyną/ chłopakiem przez to, że grałem/am } \\
\text { na pieniądze/rzeczy. }\end{array}$ & 70 & 1 & 0 & 1 & 0,04 \\
\hline $\begin{array}{l}\text { Przy kolejnych grach zwiększałem/am sumy } \\
\text { i wartość rzeczy, o które grałem/am }\end{array}$ & 63 & 5 & 1 & 4 & 0,00 \\
\hline
\end{tabular}




\begin{tabular}{|l|c|c|c|c|c|}
\hline & $\begin{array}{c}\text { Ani razu } \\
\%\end{array}$ & $\begin{array}{c}1-2 \text { razy } \\
\%\end{array}$ & $\begin{array}{c}\text { Kilka } \\
\text { razy } \\
\%\end{array}$ & $\begin{array}{c}\text { Kilkana- } \\
\text { ście razy } \\
\text { i więcej } \\
\%\end{array}$ & p.i*. \\
\hline $\begin{array}{l}\text { Gdy stawiałem/am wysokie dla mnie sumy/cen- } \\
\text { ne rzeczy odczuwałem/am dużą przyjemność }\end{array}$ & 64 & 4 & 3 & 3 & 0,00 \\
\hline $\begin{array}{l}\text { Nawet, kiedy przegrywałem/am nie kończyłem/ } \\
\text { am gry, aż wszystko straciłem/an }\end{array}$ & 63 & 4 & 3 & 3 & 0,01 \\
\hline $\begin{array}{l}\text { Z przyjemnością rozmyślałem/am o wcześniej- } \\
\text { szych wygranych, przypominałem/am sobie } \\
\text { sytuacje, kiedy grałem/am }\end{array}$ & 57 & 6 & 5 & 4 & 0,00 \\
\hline $\begin{array}{l}\text { Grałem/am na pieniądze/rzeczy, żeby poczuć się } \\
\text { przyjemnie, poprawić sobie humor }\end{array}$ & 59 & 7 & 4 & 2 & n.i. \\
\hline $\begin{array}{l}\text { Grałem/am na pieniądze/rzeczy, żeby poczuć się } \\
\text { przyjemnie, poprawić sobie humor }\end{array}$ & 67 & 3 & 1 & 2 & 0,00 \\
\hline $\begin{array}{l}\text { Zawalałem/am noce lub byłem/am niewyspany/a } \\
\text { przez to, że gram na pieniądze/rzeczy }\end{array}$ & 67 & 4 & 0 & 2 & 0,00 \\
\hline $\begin{array}{l}\text { Mówiłem/am, że jestem starszy/a albo korzy- } \\
\text { stałem/am z pomocy osoby pełnoletniej, żeby } \\
\text { pozwolono mi zagrać na pieniądze/rzeczy }\end{array}$ & 66 & 5 & 0 & 2 & n.i. \\
\hline
\end{tabular}

p.i. - poziom istotności różnic między uczniami ze specjalnymi potrzebami edukacyjnymi a pozostałymi

n.i. - nieistotny statystycznie

Wyniki takie oznaczają, że ta grupa może ponosić większe konsekwencje podejmowanych zachowań ryzykownych. Wyraźnie należy jednak podkreślić, iż w zdecydowanej większości przypadków zaprezentowane wyniki dotyczą pojedynczych sytuacji (do kilku razy w ciągu roku), a rzeczywiste poważne konsekwencje ponosić mogą ci gracze, u których ma to częsty charakter (kilkanaście razy i więcej w ciągu roku). Na przykład "zawalanie" nauki w szkole w wyniku grania zadeklarowało $1 \%$ badanych uczniów. Częściowym potwierdzeniem wcześniej zaobserwowanych prawidłowości (większe rozpowszechnienie konsekwencji w grupie uczniów ze SPE) jest również wynik kolejnego porównania.

Zawężenie grupy znajomych oraz gorsze wywiązywanie się z obowiązków domowych istotnie częściej dotyczyło uczniów ze specjalnymi potrzebami edukacyjnymi, potwierdzając, że częściej uprawiają oni hazard w sposób problemowy. 
Tabela 3. Istotność różnic w zakresie rozpowszechnienia poważnych konsekwencji uprawiania hazardu między grupą uczniów ze specjalnymi potrzebami edukacyjnymi i młodych ludzi z populacji generalnej

\begin{tabular}{|l|c|c|c|}
\hline & Tak & Nie & p.i. \\
\hline $\begin{array}{l}\text { Porzuciłem/am dawnych znajomych i teraz przebywam } \\
\text { w towarzystwie osób, które lubią grać na pieniądze/rzeczy }\end{array}$ & $5(1)^{*}$ & $95(99)$ & 0,00 \\
\hline $\begin{array}{l}\text { Gorzej wywiązuję się z obowiązków domowych przez to, } \\
\text { że gram na pieniądze/rzeczy }\end{array}$ & $6(2)$ & $94(98)$ & 0,00 \\
\hline $\begin{array}{l}\text { Nie interesuję się rzeczami, które wcześniej sprawiały } \\
\text { mi dużo przyjemności, bo zajmuje mnie granie na pieniądze/ } \\
\text { rzeczy. }\end{array}$ & $3(1)$ & $97(99)$ & n.i. \\
\hline
\end{tabular}

${ }^{*}$ w nawiasie podano odsetki uczniów bez specjalnych potrzeb edukacyjnych

p.i. - poziom istotności różnic między uczniami ze specjalnymi potrzebami edukacyjnymi a pozostałymi

n.i. - nieistotny statystycznie

\section{Używanie substancji psychoaktywnych}

Jedną z prawidłowości dotyczących zachowań ryzykownych jest ich częste współwystępowanie. Kolejnym etapem analizy były wskazania respondentów, czy i jak często w ciągu całego życia używali substancji psychoaktywnych wymienionych w tabeli 4 .

Tabela 4. Rozkład częstości odpowiedzi na pytanie dotyczące używania substancji psychoaktywnych w grupie uczniów ze SPE w ciągu całego życia

\begin{tabular}{|l|c|c|c|c|}
\hline & $\begin{array}{c}\text { Nie, } \\
\text { nigdy } \\
\%\end{array}$ & $\begin{array}{c}\text { Tak, ale } \\
\text { spróbo- } \\
\text { wałem/ } \\
\text { am tylko } \\
\text { raz lub } \\
\text { dwa } \%\end{array}$ & $\begin{array}{c}\text { Tak, } \\
\text { robiłem/ } \\
\text { am to } \\
\text { wiele razy } \\
\%\end{array}$ & p.i.* \\
\hline Paliłeś/aś tytoń (papierosy, fajkę) & 47 & 28 & 25 & n.i. \\
\hline $\begin{array}{l}\text { Piłeś/aś alkohol (piwo, wino, wódkę, drinki } \\
\text { alkoholowe itp.) }\end{array}$ & 28 & 35 & 37 & 0,007 \\
\hline $\begin{array}{l}\text { Używałeś/aś („paliłeś/aś”) elektronicznego papierosa, } \\
\text { e-fajkę, „moda” }\end{array}$ & 50 & 25 & 25 & n.i. \\
\hline Brałeś/aś „,dopalacze” & 93 & 5 & 2 & n.i. \\
\hline Paliłeś/aś marihuanę/haszysz & 74 & 15 & 10 & n.i. \\
\hline Piłeś/aś napoje energetyzujące/,"energetyki” & 66 & 11 & 9 & n.i. \\
\hline
\end{tabular}

p.i. - poziom istotności w zakresie porównania rozkładów odpowiedzi uczniów ze SPE i bez SPE n.i. - nieistotny statystycznie 
Z uwagi na przejrzystość prezentowanych danych zrezygnowano z zamieszczania odsetków w grupie „,bez SPE”. Brak statystycznie istotnych różnic oznacza, że wyniki uczniów ze SPE i pozostałych są zbliżone.

Statystycznie istotna różnica (na poziomie $p=0,007$ ) między grupami uczniów z populacji generalnej i uczniami ze SPE została odnotowania w zakresie używana alkoholu w ciągu całego życia - więcej młodych ludzi bez SPE zadeklarowało takie doświadczenie, $33 \%$ spróbowało alkoholu raz lub dwa razy, a niemal połowa $(47 \%)$ zrobiła to wiele razy. Pogłębienie obrazu dotyczącego używania substancji psychoaktywnych dotyczyło określenia skali tego zjawiska w ciągu 30 dni poprzedzających badanie - jest ono wskaźnikiem bieżącego używania takich substancji.

Tabela 5. Rozkład częstości odpowiedzi na pytanie dotyczące używania substancji psychoaktywnych w grupie uczniów ze SPE w ciągu 30 dni poprzedzających badanie

\begin{tabular}{|l|c|c|c|c|c|}
\hline & $\begin{array}{c}\text { Ani razu } \\
\text { tego nie } \\
\text { robiłem/ } \\
\text { am \% }\end{array}$ & $\begin{array}{c}\text { Zro- } \\
\text { biłem/am } \\
\text { to kilka } \\
\text { razy \% }\end{array}$ & $\begin{array}{c}\text { Robiłem/ } \\
\text { am to } \\
\text { kilka razy } \\
\text { w ty- } \\
\text { godniu \% }\end{array}$ & $\begin{array}{c}\text { Robiłem/ } \\
\text { am to co- } \\
\text { dziennie } \\
\text { lub pra- } \\
\text { wie co- } \\
\text { dziennie } \\
\%\end{array}$ & p.i. \\
\hline Paliłeś/aś tytoń (papierosy, fajkę) & 69 & 14 & 5 & 11 & n.i. \\
\hline $\begin{array}{l}\text { Piłeś/aś alkohol (piwo, wino, wódkę, } \\
\text { drinki alkoholowe itp.) }\end{array}$ & 50 & 36 & 10 & 2 & n.i. \\
\hline $\begin{array}{l}\text { Używałeś/aś („paliłeś/aś”) elektroniczne- } \\
\text { go papierosa, e-fajkę, "moda” }\end{array}$ & 66 & 17 & 7 & 10 & n.i. \\
\hline Brałeś/ás „dopalacze” & 98 & 1 & 0 & 1 & n.i. \\
\hline Paliłeś/aś marihuanę/haszysz & 86 & 8 & 2 & 3 & n.i. \\
\hline $\begin{array}{l}\text { Piłeś/aś napoje energetyzujące/,energe- } \\
\text { tyki" }\end{array}$ & 46 & 33 & 14 & 6 & n.i. \\
\hline
\end{tabular}

p.i. - poziom istotności

n.i. - nieistotny statystycznie

Brak różnic pokazuje, że w zakresie używania substancji psychoaktywnych w stosunkowo krótkim czasie poprzedzającym badanie (30 dni) porównywane grupy są do siebie bardzo podobne. Rozpowszechnienie analizowanych zachowań należy uznać jako znaczące, ponieważ przynajmniej jeden raz w ciągu miesiąca tzw. energetyki piła połowa badanych uczniów ze SPE (53\%), niewiele mniej młodych ludzi piło alkohol - 48\%, e-papierosy używało $34 \%$ respondentów, palenie tytoniu - 30\%, palenie marihuany/haszyszu - 13\%, a konsumpcja dopalaczy $2 \%$. Warto zwrócić uwagę, że picie alkoholu jest bardziej rozpowszechnione w badanej grupie niż palenie tytoniu. 


\section{Zaangażowanie w przemoc rówieśniczą}

Kolejnym analizowanym zachowaniem ryzykownym jest zaangażowanie w przemoc rówieśniczą. Szczególnie ważną kwestią jest narażenie na stanie się jej ofiarą uczniów ze specjalnymi potrzebami edukacyjnymi zarówno w wersji tradycyjnej, jak i elektronicznej (cyberbullying). Najbardziej rozpowszechnione w literaturze stanowisko mówi, że grupa taka jest szczególnie narażona na wiktymizację rówieśniczą, aczkolwiek dość powszechnym stanowiskiem jest również, że te same czynniki prowadzą zarówno do stawania się ofiarą, jak i sprawcą przemocy (np. Rose, Monda i Esplage 2011). Wyraźnie należy odróżnić zjawisko agresji rówieśniczej od przemocy, dręczenia (bullyingu), które charakteryzuje się intencjonalnością wrogich działań, powtarzalnością (trwaniem w czasie) oraz nierównowagą sił między sprawcą a ofiarą, która z tego powodu nie może się skutecznie bronić. Badani uczniowie w kwestionariuszu mieli określić częstotliwość sprawstwa lub/i wiktymizacji, odnosząc się do opisanej im sytuacji precyzującej pojęcie dręczenia: „Dręczenie polega na tym, że uczeń lub grupa uczniów często mówi lub robi innemu uczniowi/uczennicy bardzo przykre, dokuczliwe rzeczy, przed którymi trudno mu/jej się obronić (np. przezywa go, bije czy wyklucza z grupy). Zaznacz jak często opisana sytuacja miała miejsce w ciągu ostatnich 12 miesięcy".

Tabela 6. Porównanie zaangażowania w bullying tradycyjny uczniów z i bez specjalnych potrzeb edukacyjnych (W nawiasach podane są odsetki uczniów bez tzw. specjalnych potrzeb edukacyjnych)

\begin{tabular}{|l|c|c|c|c|c|}
\hline \multicolumn{1}{|c|}{ Bullying (dręczenie tradycyjne) } & $\begin{array}{c}\text { Nie zda- } \\
\text { rzyła mi } \\
\text { się taka } \\
\text { sytuacja } \\
\%\end{array}$ & $\begin{array}{c}\text { Zdarzyła } \\
\text { mi się } \\
\text { jeden raz } \\
\%\end{array}$ & $\begin{array}{c}\text { Zdarzyła } \\
\text { mi się 2-3 } \\
\text { razy } \\
\%\end{array}$ & $\begin{array}{c}\text { Zdarzyła } \\
\text { mi się 4 } \\
\text { razy lub } \\
\text { więcej } \\
\%\end{array}$ & p.i. \\
\hline Ty dręczyłeś/aś innych uczniów & $72(73)$ & $14(14)$ & $7(8)$ & $7(5)$ & n.i. \\
\hline $\begin{array}{l}\text { Inny uczeń bądź uczniowie dręczyli } \\
\text { Ciebie }\end{array}$ & $64(72)$ & $15(14)$ & $10(7)$ & $10(6)$ & 0,05 \\
\hline
\end{tabular}

p.i. - poziom istotności

n.i. - nieistotny statystycznie

Wydaje się, że zaobserwowany zakres zaangażowania w przemoc rówieśniczą należy uznać jako znaczący. W grupie badanych uczniów ze specjalnymi potrzebami edukacyjnymi sprawcami, w ciągu 12 miesięcy przed badaniem, był co trzeci z nich (28\%), a wiktymizacji doświadczyło aż 35\% (dla porównania w grupie bez specjalnych potrzeb edukacyjnych było to $27 \%$ ). Zatem uczniowie ze SPE istotnie częściej byli ofiarami tradycyjnej przemocy rówieśniczej, co po- 
twierdza przyjmowane założenia o podwyższonym ryzyku krzywdzenia tej grupy uczniów ukazywane w przywoływanych wcześniej badaniach.

Dręczenie może być realizowane również z wykorzystaniem nowych mediów (Internetu) (Dooley, Pyżalski, Cross 2009; Pyżalski 2012). Podobnie jak $\mathrm{w}$ przypadku badania rozpowszechnienia bullyingu tradycyjnego, uczniowie byli pytani, czy w czasie 12 miesięcy poprzedzających badanie byli ofiarą takiej sytuacji: „Jedna lub kilka osób z Twojej szkoły/klasy dręczyło Cię korzystając z Internetu lub telefonów komórkowych/smartfonów - przez dłuższy czas (regularnie) w taki sposób, że cierpiałeś i trudno było Ci się obronić?" i czy sami zrealizowali wobec kogoś opisane zachowanie.

Tabela 7. Porównanie zaangażowania w cyberbullying uczniów z i bez specjalnych potrzeb edukacyjnych (w nawiasach podane są odsetki uczniów bez tzw. specjalnych potrzeb edukacyjnych)

\begin{tabular}{|l|c|c|c|c|c|}
\hline \multicolumn{1}{|c|}{ Cyberbullying } & $\begin{array}{c}\text { Nie zda- } \\
\text { rzyła } \\
\text { mi się taka } \\
\text { sytuacja } \\
\%\end{array}$ & $\begin{array}{c}\text { Zdarzyła } \\
\text { mi się je- } \\
\text { den raz } \\
\%\end{array}$ & $\begin{array}{c}\text { Zdarzyła } \\
\text { mi się 2-3 } \\
\text { razy } \\
\%\end{array}$ & $\begin{array}{c}\text { Zdarzyła } \\
\text { mi się } \\
\text { 4 razy lub } \\
\text { więcej } \\
\%\end{array}$ & p.i. \\
\hline Ty dręczyłeś/aś innych uczniów & $89(92)$ & $7(6)$ & $2(2)$ & $3(1)$ & n.i. \\
\hline $\begin{array}{l}\text { Inny uczeń bądź uczniowie dręczyli } \\
\text { Ciebie }\end{array}$ & $84(90)$ & $9(6)$ & $4(2)$ & $2(1)$ & 0,01 \\
\hline
\end{tabular}

p.i. - poziom istotności

n.i. - nieistotny statystycznie

Rozpowszechnienie sprawstwa cyberbullyingu ( $w$ ciągu roku poprzedzającego badanie) w grupie uczniów ze SPE wyniosło łącznie 12\% próby, natomiast ofiary stanowiły jej $15 \%$. Podobnie jak w przypadku zaangażowania w tradycyjne dręczenie, zaobserwowano brak istotnych różnic w zakresie sprawstwa oraz istotnie większy odsetek uczniów ze specjalnymi potrzebami edukacyjnymi, które stały się ofiarami cyberbullyingu. Potwierdziła się w ten sposób teza o podwyższonej wrażliwości na stanie się uczniów ze SPE, ofiarą zarówno tradycyjnych, jak i internetowych form przemocy rówieśniczej.

\section{Podsumowanie i wnioski}

W zależności od rodzaju zachowania hazardowego, wyniki pokazują, że przynajmniej jeden raz $\mathrm{w}$ roku poprzedzającym badanie zrealizowało je od $8 \%$ do 54\% uczniów ze specjalnymi potrzebami edukacyjnymi (tych, którzy twierdząco odpowiedzieli na pytanie o posiadaniu orzeczenia o niepełnospraw- 
ności lub innego podobnego dokumentu np. o dysleksji). O ile ryzyko hazardu patologicznego jest niskie ( $\mathrm{w}$ całej próbie było 1,3\% osób spełniających kryteria uzależnienia DSM-V, w tym łagodne nasilenie dotyczyło $0,8 \%$ próby), to rozpowszechnienie używania substancji psychoaktywnych i zaangażowania $\mathrm{w}$ przemoc rówieśniczą (bullying), zarówno tradycyjną, jak i realizowaną za pomocą TIK należy uznać za znaczące. Porównanie z uczniami bez specjalnych potrzeb edukacyjnych wykazało istotne różnice zarówno w zakresie częstotliwości realizowania zachowań hazardowych, jak i skali nasilenia problemów z tego wynikających (z reguły większe natężenie obserwowano w grupie uczniów ze SPE). Zarysowała się również tendencja do większej częstotliwości zachowań realizowanych za pomocą Internetu przez takich młodych ludzi. W zakresie używania substancji psychoaktywnych w zdecydowanej większości nie wystąpiły istotne różnice międzygrupowe. Potwierdziło się występowanie większego ryzyka stania się ofiarą przemocy (bullyingu i cyberbullyingu) w przypadku uczniów ze SPE.

Ograniczona wiedza na temat zaangażowania młodych ludzi ze specjalnymi potrzebami edukacyjnymi wymaga poszerzenia za pomocą różnych perspektyw metodologicznych zarówno jakościowej, ilościowej, jak i tzw. podejścia mieszanego (mixed methods research design/multimethodology), szczególnie zaś:

1. należy podjąć działania służące rozpoznaniu skali zachowań ryzykownych w poszczególnych grupach młodych ludzi z niepełnosprawnościami, specjalnymi potrzebami edukacyjnymi (tematyka ta częściej podejmowana jest w odniesieniu do osób dorosłych z niepełnosprawnościami). Obecne badanie traktuje tę grupę jako jednorodną, co nie pozwala na zdiagnozowanie specyfiki odnoszącej się do poszczególnych potrzeb specjalnych Szczególną uwagę należy poświęcić kwestii wiktymizacji, używaniu środków psychoaktywnych oraz funkcjonowania $\mathrm{w}$ roli użytkownika nowych mediów (Internetu);

2. należy $\mathrm{w}$ badaniach poszukiwać uwarunkowań, a także czynników ryzyka oraz czynników chroniących. Te ostatnie są często nieuwzględniane, co sprawia, że wartość aplikacyjna badań w kontekście praktyki profilaktycznej jest niższa;

3. należy rozpoznać istniejące działania profilaktyczne i zaradcze adresowane do populacji uczniów ze specjalnymi potrzebami edukacyjnymi oraz dokonać ich ewaluacji;

4. warto konstruować nowe programy profilaktyczne dotyczące zachowań ryzykownych w grupie uczniów ze SPE, uwzględniając zarówno uwarunkowania uniwersalne, jak i te specyficzne dla specjalnych potrzeb.

Pewnym ograniczeniem dla interpretacji prezentowanych wyników jest brak możliwości precyzyjnego wyodrębnienia, kto znalazł się w grupie zdefiniowanej jako uczniowie ze specjalnymi potrzebami edukacyjnymi. Kolejnym krokiem powinno być rozpoznawanie problemów zachowań ryzykownych wraz z ich uwa- 
runkowaniami, współzależnościami w bardziej homogenicznych grupach młodych ludzi wymagającymi pomocy psychologiczno-pedagogicznej i/lub posiadających orzeczenia o potrzebie kształcenia specjalnego.

\section{Bibliografia}

Borowska-Beszta B. (2006), Samotność po godzinach - o nadużywaniu alkoholu przez osoby niepetnosprawne umysłowo, „Wychowanie Na Co Dzieńn”, nr 10-11, s. 31-34.

Brunelle N., Leclerc D., Cousineau M.M., Dufour M., Gendron A., Martin I. (2012), Brief report. Internet Gambling, Substance Use, and Delinquent Behavior: An Adolescent Deviant Behavior Involvement Pattern, „Psychology of Addictive Behaviors”, no. 26(2), s. 364-370.

Chrzanowska I. (2015), Pedagogika specjalna. Od tradycji do wspótczesności, Oficyna Wydawnicza „Impuls”, Kraków.

Clark C., Nower L., Walker D.M. (2013), The relationship of ADHD symptoms to gambling behaviour in the USA: results from the National Longitudinal Study of Adolescent Health, „International Gambling Studies", vol. 13(1), s. 37.

Dooley J.J., Pyżalski J., Cross D.( 2009), Cyberbullying Versus Face-to-Face Bullying: A Theoretical and Conceptual Review, "Zeitschrift für Psychologie" / "Journal of Psychology", vol. 217(4), s. $182-188$.

Gibbs Van Brunschot E. (2009), Gambling and Risk Behaviour: A Literature Review, Prepared for the Alberta Gaming Research Institute.

http://www.assembly.ab.ca/lao/library/egovdocs/2009/algri/173320.pdf [dostęp: 03.04.2016].

Gwiazda M. (2015), Pracoholicy, siecioholicy, hazardziści... Uzależnienia od zachowań, Komunikat z badań CBOS, www.cbos.pl/SPISKOM.POL/2015/K_076_15.PDF [dostęp: 03.04.2016].

Donovan J.E., Jessor R.J. (1985), Structure of problem behavior in adolescence and young adulthood, "Journal of Consulting and Clinical Psychology", vol. 53(6), s. 890-904.

Dowling N.A., Brown M.M. (2010), Commonalities in the Psychological Factors Associated with Problem Gambling and Internet Dependence, „Cyberpsychology, Behavior \& Social Networking", vol. 13(4), s. 437-441.

Groombridge S., Gordon A., Tierney K. (2000), Innovative approaches to problem gambling for people with intellectual disability, "Journal of Intellectual Disability Research".

Gupta R., Derevensky J. (2008), Gambling behaviors of Florida college students, Report prepared for the Florida Council on Compulsive Gambling, Florida.

Hintze B. (2011), Wybrane przekonania i doświadczenia zwiq̨ane z piciem alkoholu i paleniem marihuany wśród młodzieży z niepetnosprawnością ruchową i ich rówieśników bez dysfunkcji, „Alkoholizm i Narkomania", nr 4, s. 297-314.

Lipińska-Lokś J. (2014), Zachowania ryzykowne młodzieży z niepetnosprawnościa, „Interdyscyplinarne Konteksty Pedagogiki Specjalnej", nr 7, s. 9-26.

Jacobs D.F. (2004), Youth gambling in North America: Long-term and future prospects [w:] Gambling problems in youth: Theoretical and applied perspectives, red. J. Derevensky, R. Gupta, Kluwer Academic/Plenum Press Publishers, NewYork, NY, s. 1-26.

Jarczyńska J. (2014), Hazard wśród młodzieży [w:] Uzależnienia behawioralne i zachowania problemowe młodzieży. Terapia, diagnoza, profilaktyka, terapia, red. J. Jarczyńska, Wydawnictwo Uniwersytetu Kazimierza Wielkiego, Bydgoszcz, s. 72-93. 
Little L (2002), Middle-class mothers' perceptions of peer and sibling victimization among children with Asperger'ssyndrome and nonverbal learning disorders, „Issues in Comprehensive Pediatric Nursing", no. 25, s. 43-57.

McBrien J., Hodgetts A., Gregory J. (2003), Offending and risky behaviour in community services for people with intellectual disabilities in one local authority, "Journal of Forensic Psychiatry \& Psychology", vol. 14(2), s. 280.

Mishna F. (2003), Learning disabilities and bullying: Double jeopardy, ,IJournal of Learning Disabilities", no. 36, s. 336-347.

Nabuzoka D. (2003), Teacher Ratings and Peer Nominations of Bullying and Other Behaviour of Children with and Without Learning Difficulties, „Educational Psychology”, vol. 23(3), s. 307-321.

Parker J.D., Summerfeldt L.J., Taylor R.N., Kloosterman P.H., Keefer K.V. (2013), Problem gambling, gaming and Internet use in adolescents: Relationships with emotional intelligence in clinical and special needs samples, Personality and Individual Differences, 55 (Special Issue on the life history approach to human differences: J. Philippe Rushton in Memoriam), s. 288-293.

Plichta P. (2013), Młodzi użytkownicy nowych mediów z niepetnosprawnościa intelektualna. Między korzyściami i zagrożeniami, „Dziecko Krzywdzone”, t. 12 nr 1, s. 121-138, http://dzieckokrzywdzone.fdn.pl/sites/default/files/file/kwartalnik/Vol_12_Nr_1_42/Plichta_P_2013_ Mlodzi_uzytkownicy_nowych_mediow.pdf [dostęp: 3.04.2016].

Plichta P., Olempska-Wysocka M. (2013), Narażenie na agresję rówieśnicza niepetnosprawnych uczniów szkót integracyjnych w relacjach nauczycieli wspomagających, „Studia Edukacyjne” 2013, nr 28, s. 169-189, https://repozytorium.amu.edu.pl/jspui/bitstream/10593/11563/1/ 169-190.pdf [dostęp: 3.04.2016].

Pyżalski J. (2010), Polscy nauczyciele i uczniowie a agresja elektroniczna - zarys teoretyczny i najnowsze wyniki badań [w:] Człowiek i uzależnienia, red. M. Jędrzejko, D. Sarzała, Akademia Humanistyczna im. Aleksandra Gieysztora, Oficyna Wydawnicza ASPRA-JR, PułtuskWarszawa, s. 103-106.

Pyżalski J. (2012), Agresja elektroniczna i cyberbullying jako nowe ryzykowne zachowania młodzieży, Oficyna Wydawnicza „Impuls”, Kraków.

Pyżalski J., Petrykowska A., Plichta P. (2015), Łódzki Kwestionariusz Problemów Hazardowych wśród Adolescentów ŁKPHA - badania na użytek konstrukcji i walidacji narzędzia [w:] Hazard i inne uzależnienia behawioralne: doniesienia z badań, red. I. Niewiadomskia, Polska Fundacja Pomocy Humanitarnej, Polska Fundacja Pomocy Humanitarnej „Res Humanie”, Warszawa, s. 77-94.

Rose C.A., Monda-Amaya L.E., Espelage D.L. (2011), Bullying Perpetration and Victimization in Special Education: A Review of the Literature, „Remedial \& Special Education”, vol. 32(2), s. 114.

Rose C.A., Espelage D.L, Monda-Amaya L.E., Shogren K.A., Aragon S.R. (2015), Bullying and Middle School Students With and Without Specific Learning Disabilities: An Examination of Social-Ecological Predictors, "Journal of Learning Disabilities", vol. 48(3), s. 239-254.

Rose R., Howley M., Fergusson A., Jament J. (2009), Mental health and special educational needs: exploring a complex relationship, "British Journal of Special Education”, vol. 36(1), s. 3-8.

Sklar A., Martin I., Gupta R., Derevensky J. (2008), Know Limits. A game to teach youth about the risks associated with excessive gambling, McGill University, Montreal. 
Vitaro F., Brendgen M., Ladouceur R., Tremblay R.E. (2001), Gambling, Deliquency, and Drug Use During Adolscence: Mutual Influence and Common Risk Factors, "Journal of Gambling Studies", vol. 17(3), s. 171-190.

Wanner B., Vitaro F., Ladouceur R., Brendgen M., Tremblay R. E. (2006), Joint trajectories of gambling, alcohol and marijuana use duringadolescence: A person- and variable-centered developmental approach, "Addictive Behaviors”, no. 31, s. 566-580.

Winters K.C, Anderson N. (2000), Gambling Involvement and Drug Use Among Adolescents, "Journal of Gambling Studies", vol. 16(2/3), s. 175-198.

Woronowicz B.T. (2011), Hazard - wyzwaniem dla profilaktyki, „Remedium”, vol. 11(225), s. $1-3$.

Ybarra M.L., Mitchell K.J. (2004), Online aggressor/targets, aggressors, and targets: A comparison of associated youth characteristics, "Journal of Child Psychology and Psychiatry", vol. 45(7), s. 1308-1316.

Ybarra M.L., Mitchell K.J., Lenhart A. (2010), Cyberbullying research in the United States [w:] Cyberbullying: A cross-national comparison, red. J. Mora-Merchan, T. Jaeger, Verlag Empirische Padagogik, Landau, s. 232-244. 